\title{
Test-Methods on the Test-Bench: A Comparison of Complete Exhaust and Exhaust Particle Extracts for Genotoxicity/Mutagenicity Assessment
}

\author{
Sandro Steiner, ${ }^{\dagger}$ Norbert V. Heeb, ${ }^{\ddagger}$ Jan Czerwinski, ${ }^{\S}$ Pierre Comte, ${ }^{\S}$ Andreas Mayer, ${ }^{\|}$Alke Petri-Fink, ${ }^{\dagger}$ \\ and Barbara Rothen-Rutishauser* ${ }^{\dagger}$ \\ ${ }^{\dagger}$ Adolphe Merkle Institute, University of Fribourg, 1700 Fribourg, Switzerland \\ ${ }^{\ddagger}$ EMPA, Swiss Federal Laboratories for Materials Testing and Research, 8600 Dubendorf, Switzerland \\ ${ }^{\S}$ Bern University of Applied Sciences, 2560 Nidau, Switzerland \\ "TTM, Technik Thermische Maschinen, 5443 Niederrohrdorf, Switzerland
}

Supporting Information

\begin{abstract}
With the growing number of new exhaust after-treatment systems, fuels and fuel additives for internal combustion engines, efficient and reliable methods for detecting exhaust genotoxicity and mutagenicity are needed to avoid the widespread application of technologies with undesirable effects toward public health. In a commonly used approach, organic extracts of particulates rather than complete exhaust is used for genotoxicity/ mutagenicity assessment, which may reduce the reliability of the results. In the present study, we assessed the mutagenicity and the genotoxicity of complete diesel exhaust compared to an organic exhaust particle extract from the same diesel exhaust in a bacterial and a eukaryotic system, that is, a complex human lung cell model. Both, complete exhaust and organic extract were found to act mutagenic/genotoxic, but the amplitudes of the effects differed considerably. Furthermore, our data indicate that the nature of the mutagenicity may not be identical for complete exhaust and particle extracts. Because in addition, differences between the responses of the different biological systems were found, we suggest that a comprehensive assessment of

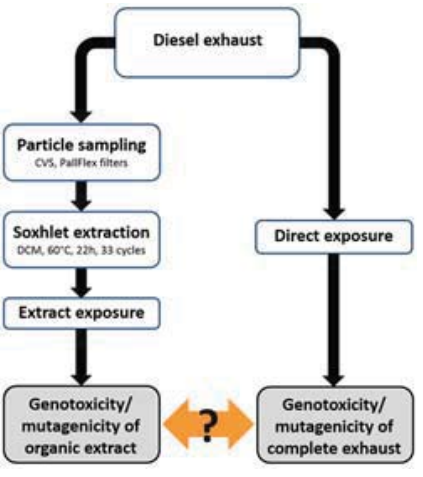
exhaust toxicity is preferably performed with complete exhaust and with biological systems representative for the organisms and organs of interest (i.e., human lungs) and not only with the Ames test.
\end{abstract}

\section{INTRODUCTION}

In June 2012, the International Agency for Research on Cancer (IARC) classified diesel engine exhaust as a group 1 carcinogen to humans (IARC press release 213, June 12th, 2012). The IARC stated that with this new classification, "governments and other decision-makers have a valuable evidence-base on which to consider environmental standards for diesel exhaust emissions and to continue to work with the engine and fuel manufacturers toward those goals". A large number of experimental studies in this field clearly supports the classification of diesel exhaust as carcinogen: Diesel exhaust or parts of diesel exhaust induce DNA damages or act mutagenic in cell cultures, ${ }^{1}$ cell-free systems, ${ }^{2}$ bacteria, ${ }^{3-5}$ or in vivo. ${ }^{6}$ But, as the IARC also stated: "it is not yet clear how the quantitative and qualitative changes" in exhaust composition "may translate into altered health effects" and that "research into this direction is needed".

Diesel exhaust is a very complex mixture, consisting of gaseous, condensed (liquid), and solid particulate fractions, all of which contribute to genotoxicity, ${ }^{7}$ the potential of a substance to damage genetic material and hence to act mutagenic and cancerogenic (mutagenicity is a possible consequence of genotoxicity and is characterized by the changes in the genetic material being permanent and hereditary). The gas phase consists of inorganic gases, such as carbon monoxide, carbon dioxide, nitrogen oxides, and a variety of volatile and semivolatile organic compounds.

Among those, most notably heterocyclic aromatic compounds (HACs) and polyaromatic hydrocarbons and their nitrated forms (PAHs/NPAHs) may directly interact with DNA by intercalation between the stacked bases, DNA adduct formation or the formation of abasic sites. ${ }^{8,9}$ The ultimate result is the loss of bases or the incorporation of additional or wrong bases during DNA replication. Furthermore, reactive oxygen and nitrogen species (ROS/RNS), such as nitric oxide (NO), nitrogen dioxide $\left(\mathrm{NO}_{2}\right)$, hydrogen peroxide $\left(\mathrm{H}_{2} \mathrm{O}_{2}\right)$, or the hydroxyl radical $\left({ }^{\bullet} \mathrm{OH}\right)$, which are present in the exhaust or can be formed intracellularly by the chemical activity or metabolism of organic components, may cause DNA strand breaks and the formation of DNA adducts. ${ }^{10-13}$ 
The particulate fraction of diesel exhaust consists of particles with a core of graphitized elemental carbon, metal particles, and nucleation mode particles made up of condensed semivolatile organic compounds. ${ }^{10,14,15}$ Besides the genotoxic activity of the adsorbed organic species, the solid (carbon or metal) particle cores on their own further contribute to genotoxicity via the formation of ROS and RNS by Fenton-type reactions. ${ }^{10}$

Genotoxicity as a direct result of the interaction between biological systems and diesel exhaust is referred to as primary genotoxicity. For the particulate fraction, an additional mechanism, referred to as secondary genotoxicity, has been described. ${ }^{20} \mathrm{~A}$ large fraction of the particles in diesel exhaust is below $100 \mathrm{~nm}$ in diameter and may reach the very distal sites of the respiratory tract, where particle clearance is slow or may even fail in case of particle overload. ${ }^{21}$ Persistent presence of particles on the lung surface may result in the induction of local inflammation which is accompanied by immune-cell mediated formation of ROS and hence-secondary-genotoxicity. ${ }^{12,20,22}$ Similarly, secondary genotoxicity may arise from the inhalation of hydrocarbons that stimulate pro-inflammatory reactions. ${ }^{23}$

Among the most commonly used approaches for testing engine emissions for their genotoxic or mutagenic potential is the measurement of the in vitro genotoxicity/mutagenicity of organic extracts produced from sampled exhaust particles. Because of the complexity of diesel exhaust, however, organic extracts may not be sufficient in this regard. Depending on their physicochemical properties, on engine loads, exhaust gas temperatures and exhaust dilution ratio, variable proportions of various PAHs and NPAHs are bound to particles or present in the liquid- and gas-phase. ${ }^{18,19}$ Specific genotoxic PAHs and NPAHs such as benzo(a)pyrene, chrysene, benzo(b)fluoranthene, 1-nitropyrene, and others have been identified in filtered exhaust indicating that these compounds are volatile enough to penetrate a diesel particle filter and hence must remain in the gas or liquid phase. ${ }^{16,17}$

Collection of the complete set of condensable carbonaceous compounds and particle-extractable compounds is possible though, however, besides being labor-intensive, such procedures still do not allow accounting for possible effects of noncondensable gaseous compounds as for example nitrogen oxides, and it cannot be excluded that the sampling and extraction procedures affect the chemistry of the samples. Using complete exhaust, including the particulate, condensed and gaseous fraction, that is, a direct exposure method to a stream of (diluted) engine exhaust as for instance described in ${ }^{5}$ may therefore be a more reliable approach.

The present study compares the genotoxic/mutagenic potential of complete exhaust to an organic extract that was produced from particles collected from the same exhaust. The aim was to obtain a measure on whether genotoxicity/ mutagenicity analysis using organic extract describes the actual activity of complete exhaust accurately or not.

Genotoxicity/mutagenicity-measurements were performed in two ways: (i) mutagenicity was assessed by the bacterial Amestest with Salmonella typhimurium as test organism and (ii) genotoxicity via the measurement of expression levels of genes involved in DNA repair, apoptosis, and cell cycle regulation in a triple cell coculture model of the human airway epithelium. ${ }^{24}$ Experiments with complete exhaust were conducted in an exhaust-exposure system that allows for in vitro exposure to freshly produced, complete engine exhaust at the air-liquid interface (ALI). ${ }^{25-27}$

\section{MATERIALS AND METHODS}

Test Vehicle. The test vehicle was a diesel passenger car, direct injection, empty load $1350 \mathrm{~kg}$, engine displacement 1998 $\mathrm{cm}^{3}, 60 \mathrm{~kW}$ at $4300 \mathrm{rpm}$, model year 1998, and mileage in course of the experiments: $70000-80000 \mathrm{~km}$. The applied settings are described in detail in ref 26.

Biological Test Systems. Ames Test. The Ames MPF 98/ 100 mutagenicity assay (Microplate format) kit from Xenometrix (S. typhimurium, strains TA98 and TA100) was used according to the manufacturer's guidelines. Exposures were conducted without S9 microsomal activation. This choice was made because the effects of $S 9$ are inconsistent, were found to be minor in several studies, ${ }^{3,4,28}$ and do not necessarily represent the metabolic activation that occurs in human lung tissue.

Triple-Cell Cocultures. A detailed description of the cell cultures and their production can be found in refs 24, 26, 29, and 30. Importantly, cell cultures to be exposed to complete exhaust were kept at the ALI for $24 \mathrm{~h}$ prior to exposure (acclimation to the ALI). To make sure that all cell cultures were of the same age the moment the exposures were conducted, cell cultures to be exposed to organic extract were kept submersed for another $24 \mathrm{~h}$ prior to extract exposure.

Exhaust Characterization. The exposure experiments and hence the exhaust characterization was performed at the exhaust gas control station of the Bern University of Applied Sciences in Nidau (officially accredited for exhaust gas control by the Swiss government). All measurements have been performed by qualified personal according to the requested protocols. Procedures and devices are described in ref 27.

Exhaust Exposure System and Exposure Conditions. The exposure system used has previously been described in detail. $^{25,31}$ In two separate exposure chambers, the system allows for simultaneous exposure to freshly produced, 10-fold diluted exhaust and filtered air under identical conditions, the filtered air exposure serving as negative control.

Diesel Exhaust Particle Sampling and Production of Organic Extracts. Particles were collected on Teflon-coated quartz-filters (PallFlex) in a particle measurement unit (PMU) (Horiba PMU 9000). The 6-fold diluted exhaust passed the filters with a volume flow of $40 \mathrm{~L} / \mathrm{min}$. The filters were weighted before and after particle sampling. Organic extracts were produced by Soxhlet-extraction using dichloromethane (DCM) as a solvent (reflux, $100 \mathrm{~mL}$ DCM, $22 \mathrm{~h}$ extraction, cycle duration $40 \mathrm{~min}$ ). DCM was removed by rotary evaporation and the extracts were dried in a stream of nitrogen. For exposure experiments, the extracts were redissolved in 4 $\mathrm{mL}$ of dimethyl-sulfoxide (DMSO).

Exposure of Cell Cultures/Bacteria. Cell Culture Exposures. Exposure to complete exhaust was performed for 2 or $6 \mathrm{~h}$ at the ALI with $1.2 \mathrm{~mL}$ culture medium in the basal compartment followed by $6 \mathrm{~h}$ postincubation. The conditions were kept at $37{ }^{\circ} \mathrm{C}, 5 \% \mathrm{CO}_{2}$, and $80 \%$ relative humidity. Organic extract was applied in $2 \mathrm{~mL}$ of fresh culture medium to the apical compartment $(3 \mathrm{~mL}$ of medium in the basal compartment) followed by $9 \mathrm{~h}$ incubation ( $9 \mathrm{~h}$ were chosen as the best approximation to the complete exhaust exposure, where the cells are exposed to the full load of particles during 6 $h$ postincubation and to an average of half the full load for 2 or $6 \mathrm{~h})$.

Ames Test. Bacterial cultures were exposed for 2, 4, and $6 \mathrm{~h}$ to complete exhaust and for $90 \mathrm{~min}$ to organic extract. Negative 
controls were treated with DMSO only or exposed to filtered air instead of exhaust, positive controls were treated with $2 \mu \mathrm{g} /$ $\mathrm{mL} 2$-nitrofluorene (TA98) and $0.1 \mu \mathrm{g} / \mathrm{mL}$ 4-nitroquinoline $\mathrm{N}$ oxide (TA100). Revertants were counted after $48 \mathrm{~h}$.

Dosing of Organic Extracts. On the basis of the exhaust volume used for exposures and particle sampling, the particle concentration in the exhaust and the particle deposition rate in the exposure chamber (about $0.5 \%$ as determined in previous studies ${ }^{25,27}$ ), exposure-hour-equivalents (h-equiv) of organic extract were calculated. One h-equiv corresponds to the amount of organics that could have been extracted from the particles that deposited on cell- or bacterial cultures during $1 \mathrm{~h}$ of exposure to complete exhaust.

Details of the calculation and the dosing of organic extracts are listed in Supporting Information Tables S1 and S2. Particles of high mobility do not evade filtration by PallFlex filters as efficiently as they can be assumed to evade deposition in the exposure chambers. Organic extracts were therefore produced from a higher number of particles than the calculation presumes. Since the small particles make up only a small fraction of the total particle mass and therefore of the total particle bound organic carbon, the fact that the deposition ratio in the exposure chamber must be assumed to be higher for larger particles was neglected here.

Viability Testing. The viability of the human lung cell cultures was tested by quantification of extracellular lactate dehydrogenase (LDH) activity (Cytotoxicity Detection Kit, Roche Applied Science) and by laser scanning microscopy of exposed cultures stained for nucleic acids with 4',6-diamidino2-phenylindole (DAPI) and the F-actin cytoskeleton with phalloidine-rhodamine. Positive controls for the LDH assay were treated with $500 \mu \mathrm{L}$ of $0.25 \%$ Triton X-100 for $15 \mathrm{~min}$.

For the highest dose of organic extracts, bacterial viability was tested using the LIVE/DEAD BacLight Bacterial Viability Kit L7012 (Molecular Probes).

Gene Expression Analysis. RNA isolation from exposed cell cultures was carried out using the RNeasy kit (Qiagen), cDNA synthesis was performed with the $\mathrm{RT}^{2}$ First Strand Kit (Qiagen). The expression of DNA damage-relevant genes was measured with the $\mathrm{RT}^{2}$ Profiler PCR Array for human DNA damage signaling (Qiagen), using the genes encoding hypoxanthine- and $\beta$-actin as internal standard. All materials were used according to the manufacturer's guidelines. All results originate from two independent experiments. Exposure to complete exhaust and to extract resulted in strong transcriptional induction of the genes under investigation. Since this clearly demonstrated that the cell cultures are able to respond to treatment with genotoxic compounds, we decided not to perform separate positive controls.

Data Analysis. Ames Test. According to the kit guidelines, a three-fold and higher increase in the number of revertants relative to the negative control or a clear dose response is indicative for mutagenicity. Statistical analysis was not performed.

Gene Expression Analysis. Only genes with high quality output (i.e., high reverse-transcription efficiency and absence of genomic DNA contaminations in the cDNA) were included in the data set. According to the gene annotations recorded on the UniProt Web site (www.uniprot.org), the 84 measured genes were classified into 4 groups: (a) genes involved in DNA-repair and DNA damage signaling, (b) genes involved in apoptosis, (c) genes involved in cell-cycle regulation, and (d) genes that cannot be grouped to $a-c$ (these genes were not further considered for analysis). Comparison of the performance of the Ames test and the gene expression analysis was solely based on group "a genes", since effects on cell cycle control and apoptosis cannot be translated to a bacterial system. Group "b genes" are entirely pro-apoptotic, their up-regulation can therefore be interpreted as a sign of apoptotic stimulation. The functions of group "c genes" are more complex and not unidirectional. We, therefore, considered only exposure-related changes in gene expression levels but not their functional implication as relevant for this work.

The comparison of the results obtained with organic extracts and complete exhaust was merely performed qualitatively. Quantitative comparison would not have been useful, since it is well-known that the amplitude of the responses observed in submersed cell cultures and cell cultures exposed at the airliquid interface are not the same. ${ }^{32-34}$ The comparison was based on the occurrence of responses (we defined this as a change in the fold-regulation of at least 2 between exposure and control), the nature of the responses relative to the control (does a given dose of both, exhaust and extract increase or decrease gene expression relative to the control?) and the dose-effect (does changing the dose of exhaust and extract change the responses in the same direction?).

\section{RESULTS}

Exhaust Characterization. The results of the complete exhaust characterization are published in detail elsewhere. ${ }^{26}$ Briefly, in the 10-fold diluted exhaust, 33 ppm carbon monoxide, $11 \mathrm{ppm}$ nitrogen oxides $(6.5 \mathrm{ppm}$ nitric oxide and $4.5 \mathrm{ppm}$ nitrogen dioxide), and $10 \mathrm{ppm}$ volatile hydrocarbons were detected. The particle number concentration in the diluted exhaust was $4.8 \times 10^{8}$ particles $/ \mathrm{cm}^{3}$.

Cellular and Bacterial Viability. Human lung cell viability was not impaired, as shown by quantification of extracellular LDH independently on the treatment. Treatment with Triton $\mathrm{X}-100$ (positive controls) resulted in 8-10-fold increased extracellular LDH levels (data not shown). Upon exposure to organic extract, microscopy of stained cell cultures revealed the abundance of highly condensed nucleic acids that have to be interpreted as condensed or fragmented cell nuclei (Figure 1).

Cultures of $S$. typhimurium were not affected in their viability (data not shown).

Ames Test. Strain TA100. Exposure to complete exhaust resulted in a 3-fold increase of mutagenicity after $6 \mathrm{~h}$ of exposure. More than 2400 exposure-hour-equivalents were necessary to induce a 3 -fold increase of mutagenicity using the organic particle extract (Figure $2 \mathrm{~A}$ ).

Strain TA98. Complete exhaust did not induce mutagenicity, but more than 4800 exposure-hour-equivalents of organic extract did (Figure 2B). For both strains, in each individual experimental repetition, the positive controls resulted in a fold induction in revertant formation of more than 10 (data not shown)

Genetic Responses of Human Lung Cell Cultures. Among the 84 genes that have been analyzed, 54 yielded high quality results (according to the quality controls included in the arrays) after all treatments. Of these 54 genes, 30 were classified as involved in DNA-repair, 12 as involved in apoptosis, 19 as involved in cell cycle regulation, and 7 could not be attributed to any of the three groups. Several genes were included into more than one group (DNA repair and apoptosis, one gene; DNA repair and cell cycle regulation, 5 genes; apoptosis and cell cycle regulation, 6 genes; all three groups, 1 gene). The 


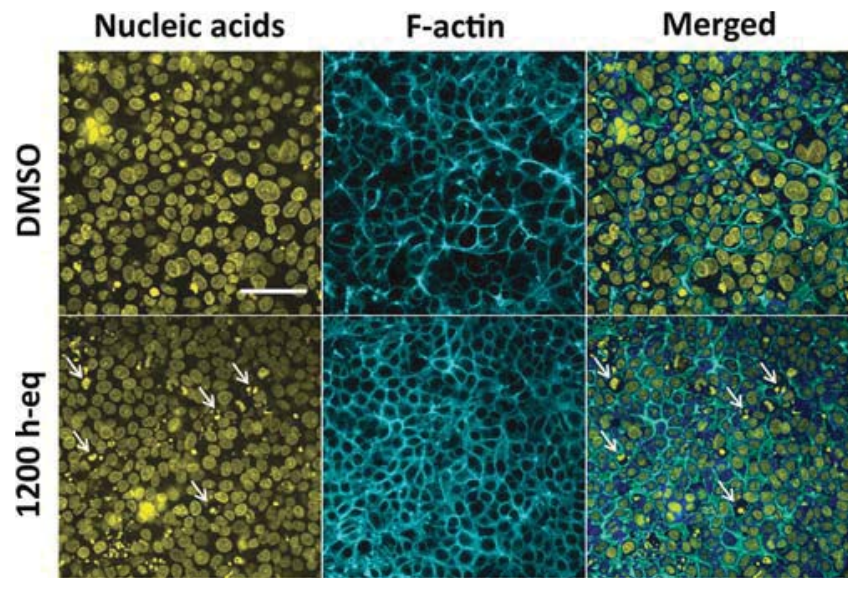

Figure 1. Laser scanning micrographs of cell cultures exposed to DMSO (control) and 1200 h-equiv of organic exhaust-particle extract. The cells were labeled for nucleic acids (DAPI, yellow) and the F-actin cytoskeleton (phalloidine-rhodamine, light blue). The organic extract resulted in a high increase in the abundance of DAPI stained, small bodies that are indicative for condensed and fragmented nuclei of cells that underwent apoptosis (some examples are indicated by white arrows). Size bar: $50 \mu \mathrm{m}$.

complete set of results is displayed as heat maps in Figure 3A$\mathrm{C}$ and a summary is given in Table 1. Exposure of human lung cell cultures to both, complete exhaust and organic extract induced genotoxicity, apoptotic stimulation, and changes in the cell cycle regulation. This was, however, found to be strongly dependent on the applied doses: For instance, upon 2 and $2 \mathrm{~h}$ equiv exposures, no induction of gene expression or even decreased gene expression levels relative to the controls was observed, whereas upon 6 and 6 h-equiv exposures, 36\% and $91 \%$ of the genes were induced. Exposures to 1200 h-equiv particle extracts resulted in increased expression for $100 \%$ of the genes. An estimate on the variability of the results was obtained by calculating the standard error of the mean (SEM) and its percentage of the average of the $\Delta \Delta$ Ct-value obtained in the two experimental repetitions (data not shown). We found that the variability is highly dependent on the gene under consideration and decreases with the applied dose. In average, SEMs were found to lie between about 20 (for 1200 h-equiv of organic extract) and $250 \%$ (for 2 h-equiv of organic extract) of the average $\Delta \Delta \mathrm{Ct}$ of all measured genes. The most part of this average SEM could be attributed to a small selection of genes that showed lower reproducibility.

\section{DISCUSSION}

The present study compares the genotoxicity/mutagenicity of complete exhaust and organic extracts obtained from collected exhaust particles using two different biological systems (i) the Ames test (Salmonella typhimurium) and (ii) a model of the human airway epithelium. The aims of the study were to evaluate whether organic extracts yield results that are representative for the genotoxicity/mutagenicity of complete exhaust and to compare a bacterial test to a human lung model. The choice of the two experimental approaches was based on the facts that (i) the Ames test is the most commonly used method for mutagenicity measurement of a wide variety of substances and (ii) a model of the human airway epithelium is of greater relevance to assess the risk of inhaled air pollution on humans, since compared to bacterial systems, responses to genotoxic/mutagenic treatment are different and more
A

TA100

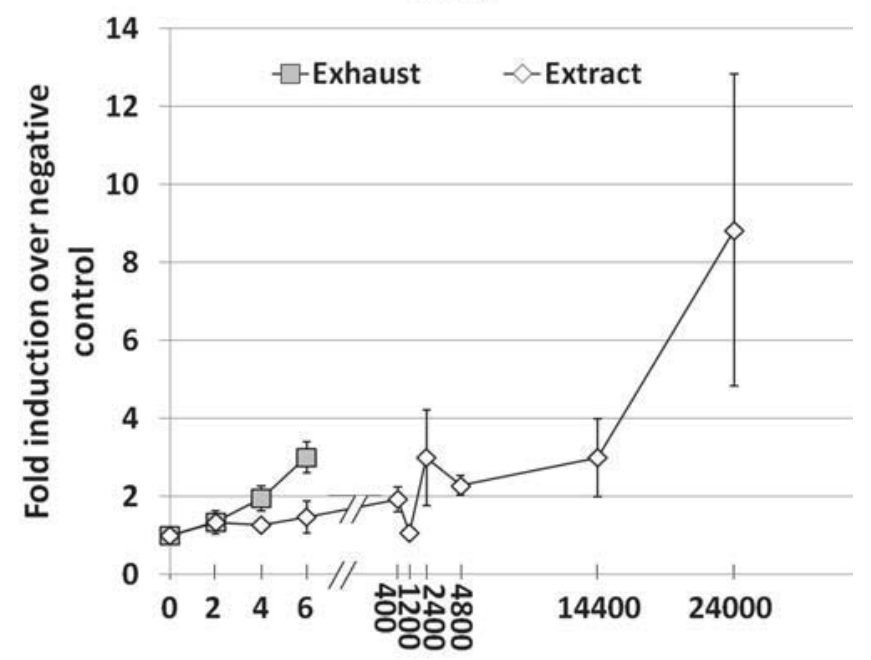

B

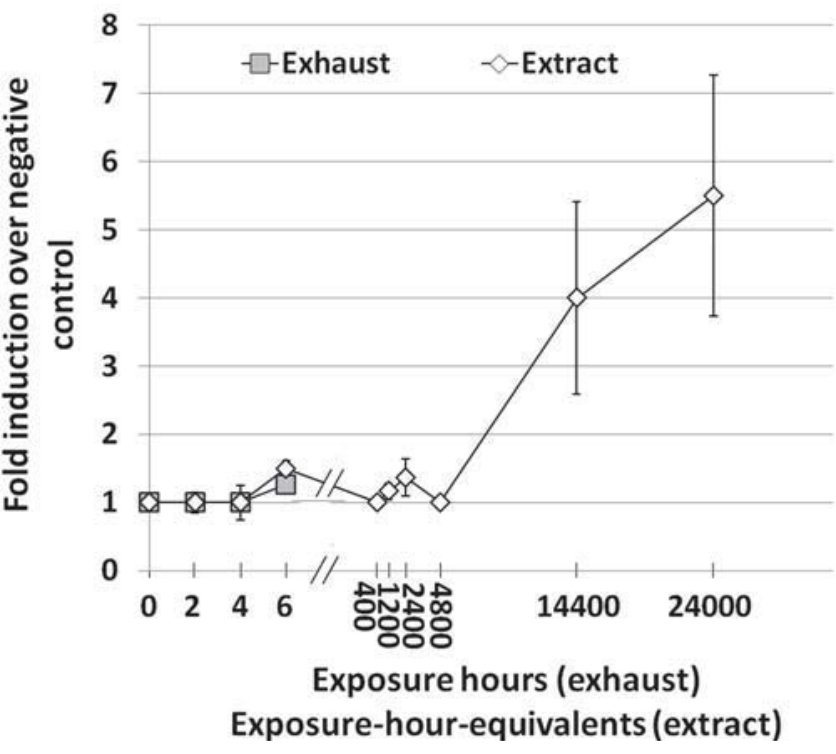

Figure 2. Ames test results for Salmonella typhimurium, strains TA100 (A) and TA98 (B). Exposure to complete exhaust was performed for 2,4 , and $6 \mathrm{~h}$, exposure to organic extract by application of 2, 4, 6, 400, $1200,2400,4800,14400$, and 24000 exposure-hour-equivalents of the extract. A fold induction over the negative control (i.e., the number of revertants upon exposure divided by the number of revertants in the control) equal to or higher than 3 indicates positive results. Controls were: DMSO for extract, filtered air exposure for complete exhaust. All experiments were repeated 4 times. Error bars indicate standard errors of the mean.

complex. The human lung cell model was composed of an epithelial cell line and two primary immune cells derived from human blood monocytes. We decided against using primary epithelial cells, because it has been shown that the biological properties of the cell cultures are not affected when cell lines are used ${ }^{35,36}$ and because the use of the epithelial cell lines provides higher purity and reproducibility.

Measuring gene expression levels for the assessment of exhaust genotoxicity in eukaryotic cells offers certain advantages over other approaches. First, nucleic acids can easily be 


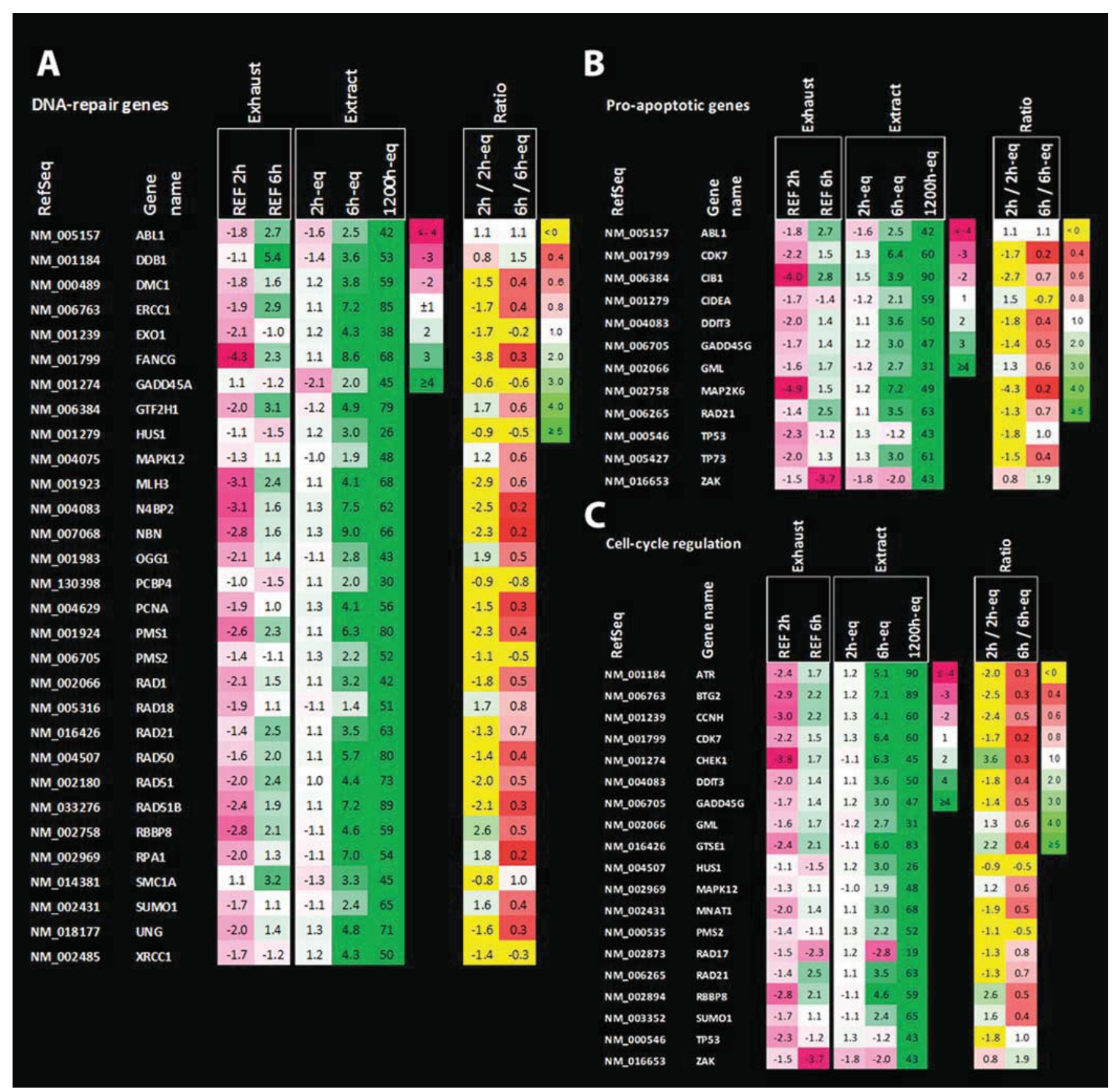

Figure 3. Transcriptional responses to exhaust/extract exposure. (A) Genes involved in DNA-repair, (B) pro-apoptotic genes, (C) genes involved in cell-cycle regulation (functional grouping according to www.uniprot.org). The amplitude of the changes is color coded, and the color code is displayed in the figures. The color ranges were set to keep differences visible and do not reflect biological relevance. In addition to the fold change in gene regulation, the ratio response to exhaust/response to extract is shown. This ratio gives information on the amplitude as well as on the direction of the responses. Negative values, highlighted in yellow, result from inverse responses, and can be considered most indicative for different effects of extract and complete exhaust. All results originate from two independent experiments.

harvested with a low risk of influencing the sample quality. This is of particular importance when sample collection has to be performed at a site as for example an exhaust gas control station, hence in absence of the equipment usually available in a biology lab. Second, nucleic acids once collected and purified, can be stored without loss in quality. It, therefore, allows storage of a complete set of information on the biological system at the time of exposure and is not restricted to one particular biological end point. Third, given that standardized protocols are available (i.e., the PCR-arrays used in this study), nucleic acids allow for a quick and unbiased sample analysis and offer a high degree of comparability among results obtained in different laboratories by different researchers. Other methods have been established to study genotoxicity, such as the Comet Assay $^{37,38}$ or the micronucleus assay; ${ }^{39}$ however, those tests are much more laborious and require more equipment at the site of exposure.

A direct comparison of the mutagenicity/genotoxicity of organic extracts and complete exhaust using different experimental approaches has to our knowledge not been performed so far, which might be a result of the difficulty in defining equivalent doses. To apply doses of the particle- 
Table 1. Numerical Evaluation of the Gene Expression Data ${ }^{a}$

\begin{tabular}{|c|c|c|c|c|c|c|c|c|c|}
\hline \multicolumn{2}{|c|}{ functional gene group } & total & $\begin{array}{l}\text { dose response } \\
\text { in the same } \\
\text { direction }^{b}\end{array}$ & $\begin{array}{l}\text { dose response in the same } \\
\text { direction and qualitatively identical } \\
\text { with respect to the controls }{ }^{c}\end{array}$ & $\begin{array}{l}\text { inverse } \\
\text { dose } \\
\text { response }\end{array}$ & $\begin{array}{l}\text { no } \\
\text { exhaust } \\
\text { effect }^{e}\end{array}$ & $\begin{array}{l}\text { no } \\
\text { extract } \\
\text { effect }^{e}\end{array}$ & $\begin{array}{l}\text { inverse response }^{f}(2 \\
\text { h, exhaust vs } 2 \text { h- } \\
\text { equiv extract })\end{array}$ & $\begin{array}{l}\text { inverse response }{ }^{f}(6 \\
\text { h, exhaust vs } 2 \text { h- } \\
\text { equiv extract) }\end{array}$ \\
\hline \multirow[t]{2}{*}{$\begin{array}{l}\text { DNA } \\
\text { repair }\end{array}$} & $\begin{array}{l}\text { number of } \\
\text { genes }\end{array}$ & 30 & 27 & 9 & 3 & 10 & 0 & 21 & 6 \\
\hline & percent & & 90 & 30 & 10 & 33 & 0 & 70 & 20 \\
\hline \multirow[t]{2}{*}{ apoptosis } & $\begin{array}{l}\text { number of } \\
\text { genes }\end{array}$ & 12 & 10 & 3 & 1 & 3 & 0 & 8 & 1 \\
\hline & percent & & 83 & 25 & 8 & 25 & 0 & 67 & 8 \\
\hline \multirow[t]{2}{*}{ cellcycle } & $\begin{array}{l}\text { number of } \\
\text { genes }\end{array}$ & 19 & 17 & 7 & 2 & 6 & 0 & 12 & 2 \\
\hline & percent & & 89 & 37 & 11 & 32 & 0 & 63 & 11 \\
\hline \multirow[t]{2}{*}{ total } & $\begin{array}{l}\text { number of } \\
\text { genes }\end{array}$ & 47 & 43 & 13 & 4 & 16 & 0 & 33 & 7 \\
\hline & percent & & 91 & 28 & 9 & 34 & 0 & 70 & 15 \\
\hline
\end{tabular}

${ }^{a_{T}}$ The numbers of genes assessed in each group showing the specified expression patterns, as well as their percentage of the number of genes in the group are displayed. ${ }^{b} \mathrm{An}$ increase in the dose of complete exhaust and extract both have the same qualitative effect on gene expression. ${ }^{c}$ At a given dose of extract and exhaust (e.g., $2 \mathrm{~h}$ exhaust and $2 \mathrm{~h}$-equiv extract), the expression level relative to the control is qualitatively the same (lower or higher) for both treatments AND a change in the dose changes the expression level qualitatively in the same way. ${ }^{d}$ When the doses of exhaust and extract are changed in the same way, gene expression levels react in the opposite way for the two treatments. ${ }^{e} \mathrm{~A}$ fold up- or down-regulation of less than 2 relative to the control is considered as the absence of an effect. ${ }^{f}$ Relative to the control, a given dose of extract and exhaust results in a lower gene expression level for one treatment and a higher gene expression level for the other (no threshold applied).

extractable organics that can be compared to the applied doses of complete exhaust, we defined exposure-hour-equivalents for the organic extract. One equivalent corresponds to the amount of organics that could be extracted from the amount of particles that directly interacted with cell- or bacterial cultures during $1 \mathrm{~h}$ of exposure to complete exhaust.

Our working hypothesis assumes that differences in the biological responses to complete exhaust and organic extract result entirely from sample processing. Whereas exhaust samples were applied in a nonprocessed form, extract formation may have had a profound effect on the genotoxic/mutagenic activity because of (i) the absence of gaseous exhaust components (e.g., $\mathrm{NO}_{2}, \mathrm{CO}$, volatile hydrocarbons) in the organic extract, (ii) extraction efficiencies that can be assumed to be below $100 \%$ and not identical for different particleadsorbed hydrocarbons, (iii) losses and chemical modifications of particle-adsorbed hydrocarbons during collection on PallFlex filters. ${ }^{31}$ However, it has to be kept in mind that the dosing was achieved in different ways for complete exhaust and extract, which may also have influenced the responses, whereas complete exhaust was dosed via the exposure time, organic extract was dosed via the applied concentration. For instance for gaseous mixtures, it has been shown that the concentration is the more important factor than the exposure time. ${ }^{40}$ Performing exhaust exposures by varying the exhaust concentration therefore could have resulted in different responses, for example, more similar to the responses the extract exposure. Nonetheless, dosing of extract and exhaust was still performed in the described way, because varying the exhaust concentration would have profoundly influenced the properties of the exhaust particles (e.g., their agglomeration state) and would therefore have decreased the comparability between the different exhaust doses. ${ }^{31}$ Dosing of extracts via their exposure time would not have allowed covering the low doses (corresponding to 2 or $6 \mathrm{~h}$ exhaust exposure) and the high doses that were needed to obtain a response with the Ames test.

Our results indicate that even though complete diesel exhaust and organic particle extracts both act genotoxic/mutagenic, the amplitude of the responses varied by orders of magnitude:
Under the reasonable assumption that complete exhaust describes exhaust genotoxicity/mutagenicity more reliably than exhaust-particle extracts, our findings imply that the Ames test performed with organic extracts underestimates the exhaust-mutagenicity considerably, whereas the human lung cell cultures showed stronger responses to the extract than to the complete exhaust.

Another interesting finding is that with the Ames-test, complete exhaust did not act mutagenic in strain TA98, whereas the organic extract did (even though only at very high doses). TA100 and TA98 detect different kinds of mutations (base-pair substitutions and frame-shift mutations, respectively), and this finding therefore opens the question whether not only the mutagenic potential, but also the nature of the mutagenicity of complete exhaust and organic extracts are not the same. A similar conclusion can be drawn from the results obtained with human lung cells: The patterns of transcriptional activation among different gene-groups reveals that genes involved in DNA-repair (Figure 3A), apoptotis (Figure 3B) and cell cycle regulation (Figure $3 \mathrm{C}$ ) respond to exhaust and extract in about the same way when only the tendencies of the dose responses are considered. When, however, the basal expression levels, i.e. the expression levels of the controls are taken into consideration, it becomes evident that the absolute expression levels show a higher variation. Only about one-third of the genes in each group showed similar expression levels upon exposure to complete exhaust or extract when compared to the controls.

In conclusion, we can say that the Ames test and human lung cell gene expression analysis are both able to detect exhaust genotoxicity/mutagenicity of both, complete exhaust and organic extracts of exhaust particles, even though with the Ames test, mutagenicity of complete exhaust could only be detected with strain TA100. In addition, the magnitude of the genotoxic/mutagenic effects strongly depends on the method and the biological system used.

Key players in the genotoxic/mutagenic action of engine exhausts are organic compounds, that is, genotoxic PAHs and NPAHs. Their distribution between the particulate, condensed/liquid and gaseous exhaust fractions is highly depend- 
ent on their physicochemical properties, on engine loads, exhaust gas temperatures, and exhaust dilution ratio. We therefore claim that reliable testing of exhaust genotoxicity and mutagenicity should be performed by direct exposure of the biological test-system to complete engine emissions rather than by using particle extracts, because only in this way, tests can account for all exhaust components. Further, since the outcome of the Ames-test depends on the used bacterial strain, we recommend using several strains for any mutagenicity assessment and/or the use of more complex eukaryotic, preferably human cell systems, that account for the more highly evolved DNA-damage detection and repair mechanisms to be found in higher animals.

\section{ASSOCIATED CONTENT}

\section{S Supporting Information}

The SI contains detailed information on the applied doses of complete exhaust and organic exhaust particle extract as well as on their calculation.

\section{AUTHOR INFORMATION}

\section{Corresponding Author}

*E-mail: barbara.rothen@unifr.ch. Phone: +41 263009502. Fax: +41263009624.

\section{Notes}

Andreas Mayer is the owner and general manager of "TTM Andreas Mayer"', Switzerland, an emission consulting company. As all the other authors, however, he declares he has no conflicts of interest.

The authors declare no competing financial interest.

\section{ACKNOWLEDGMENTS}

The authors would like to acknowledge the financial support of the Swiss Federal Office for the Environment, Erdölvereinigung EV, and VSS lubes, as well as the Adolphe Merkle Foundation. Furthermore, the Bern University of Applied Sciences, the Institute of Aerosol and Sensor Technology, Northwestern Switzerland and the University of Rouen for technical assistance. We would also like to thank Dr. Gruenert (University of California, San Francisco) for providing the16HBE14o cell line.

\section{REFERENCES}

(1) Hemmingsen, J. G.; Møller, P.; Nojgaard, J. K.; Roursgaard, M.; Loft, S. Oxidative stress, genotoxicity, and vascular cell adhesion molecule expression in cells exposed to particulate matter from combustion of conventional diesel and methyl ester biodiesel blends. Environ. Sci. Technol. 2011, 45 (19), 8545-8551.

(2) Topinka, J.; Milcova, A.; Schmuczerova, J.; Mazac, M.; Pechout, M.; Vojtisek-Lom, M. Genotoxic potential of organic extracts from particle emissions of diesel and rapeseed oil powered engines. Toxicol. Lett. 2012, 212 (1), 11-7.

(3) Bunger, J.; Krahl, J.; Baum, K.; Schroder, O.; Muller, M.; Westphal, G.; Ruhnau, P.; Schulz, T. G.; Hallier, E. Cytotoxic and mutagenic effects, particle size and concentration analysis of diesel engine emissions using biodiesel and petrol diesel as fuel. Arch. Toxicol. 2000, 74 (8), 490-498.

(4) Kooter, I. M.; van Vugt, M. A. T. M.; Jedynska, A. D.; Tromp, P. C.; Houtzager, M. M. G.; Verbeek, R. P.; Kadijk, G.; Mulderij, M.; Krul, C. A. M. Toxicological characterization of diesel engine emissions using biodiesel and a closed soot filter. Atmos. Environ. 2011, 45 (8), 1574-1580.
(5) Fall, M.; Haddouk, H.; Loriot, S.; Diouf, A.; Dionnet, F.; Forster, R.; Morin, J. P. Mutagenicity of diesel engine exhaust in the Ames/ Salmonella assay using a direct exposure method. Toxicol. Environ. Chem. 2011, 93 (10), 1971-1981.

(6) Risom, L.; Dybdahl, M.; Bornholdt, J.; Vogel, U.; Wallin, H.; Møller, P.; Loft, S. Oxidative DNA damage and defence gene expression in the mouse lung after short-term exposure to diesel exhaust particles by inhalation. Carcinogenesis 2003, 24 (11), 18471852.

(7) Westphal, G. A.; Krahl, J.; Munack, A.; Rusche, Y.; Schroder, O.; Hallier, E.; Bruning, T.; Bunger, J. Mutagenicity of diesel engine exhaust is eliminated in the gas phase by an oxidation catalyst but only slightly reduced in the particle phase. Environ. Sci. Technol. 2012, 46 (11), 6417-6424.

(8) Xue, W. L.; Warshawsky, D. Metabolic activation of polycyclic and heterocyclic aromatic hydrocarbons and DNA damage: A review. Toxicol. Appl. Pharmacol. 2005, 206 (1), 73-93.

(9) Ferguson, L. R.; Denny, W. A. Genotoxicity of non-covalent interactions: DNA intercalators. Mutat. Res., Fundam. Mol. Mech. Mutagen. 2007, 623 (1-2), 14-23.

(10) Shinyashiki, M.; Eiguren-Fernandez, A.; Schmitz, D. A.; Di Stefano, E.; Li, N.; Linak, W. P.; Cho, S. H.; Froines, J. R.; Cho, A. K. Electrophilic and redox properties of diesel exhaust particles. Environ. Res. 2009, 109 (3), 239-244.

(11) Kasai, H. Chemistry-based studies on oxidative DNA damage: Formation, repair, and mutagenesis. Free Radical Biol. Med. 2002, 33 (4), 450-456.

(12) Donaldson, K.; Tran, L.; Jimenez, L. A.; Duffin, R.; Newby, D. E.; Mills, N.; MacNee, W.; Stone, V. Combustion-derived nanoparticles: a review of their toxicology following inhalation exposure. Part. Fibre Toxicol. 2005, 2, 10.

(13) Nair, U.; Bartsch, H.; Nair, J. Lipid peroxidation-induced DNA damage in cancer-prone inflammatory diseases: A review of published adduct types and levels in humans. Free Radical Biol. Med. 2007, 43 (8), 1109-1120.

(14) Mayer, A.; Czerwinski, J.; Wichser, A.; Ulrich, A.; Kasper, M.; Mooney, J. Metal-Oxide Particles in Combustion Engine Exhaust. SAE Tech. Pap. 2010, 2010-01-0792.

(15) Burtscher, H. Physical characterization of particulate emissions from diesel engines: a review. J. Aerosol Sci. 2005, 36 (7), 896-932.

(16) Heeb, N. V.; Schmid, P.; Kohler, M.; Gujer, E.; Zennegg, M.; Wenger, D.; Wichser, A.; Ulrich, A.; Gfeller, U.; Honegger, P.; Zeyer, K.; Emmenegger, L.; Petermann, J. L.; Czerwinski, J.; Mosimann, T.; Kasper, M.; Mayer, A. Secondary effects of catalytic diesel particulate filters: Conversion of PAHs versus formation of Nitro-PAHs. Environ. Sci. Technol. 2008, 42 (10), 3773-3779.

(17) Heeb, N. V.; Schmid, P.; Kohler, M.; Gujer, E.; Zennegg, M.; Wenger, D.; Wichser, A.; Ulrich, A.; Gfeller, U.; Honegger, P.; Zeyer, K.; Emmenegger, L.; Petermann, J. L.; Czerwinski, J.; Mosimann, T.; Kasper, M.; Mayer, A. Impact of low- and high-oxidation diesel particulate filters on genotoxic exhaust constituents. Environ. Sci. Technol. 2010, 44 (3), 1078-1084.

(18) Zielinska, B.; Sagebiel, J.; Arnott, W. P.; Rogers, C. F.; Kelly, K. E.; Wagner, D. A.; Lighty, J. S.; Sarofim, A. F.; Palmer, G. Phase and size distribution of polycyclic aromatic hydrocarbons in diesel and gasoline vehicle emissions. Environ. Sci. Technol. 2004, 38 (9), 25572567.

(19) Atkinson, R; Arey, J. Atmospheric chemistry of gas-phase polycyclic aromatic-hydrocarbons-Formation of atmospheric mutagens. Environ. Health Perspect. 1994, 102, 117-126.

(20) Schins, R. P. F.; Knaapen, A. M. Genotoxicity of poorly soluble particles. Inhalation Toxicol. 2007, 19, 189-198.

(21) Oberdorster, G.; Oberdorster, E.; Oberdorster, J. Nanotoxicology: An emerging discipline evolving from studies of ultrafine particles. Environ. Health Perspect. 2005, 113 (7), 823-839.

(22) Weitzman, S. A.; Gordon, L. I. Inflammation and cancer-Role of phagocyte-generated oxidants in carcinogenesis. Blood 1990, 76 (4), $655-663$. 
(23) Podechard, N.; Lecureur, V.; Le Ferrec, E.; Guenon, I.; Sparfel, L.; Gilot, D.; Gordon, J. R.; Lagente, V.; Fardel, O. Interleukin-8 induction by the environmental contaminant benzo(a)pyrene is aryl hydrocarbon receptor-dependent and leads to lung inflammation. Toxicol. Lett. 2008, 177 (2), 130-137.

(24) Blank, F.; Rothen-Rutishauser, B.; Gehr, P. Dendritic cells and macrophages form a transepithelial network against foreign particulate antigens. Am. J. Respir. Cell Mol. Biol. 2007, 36 (6), 669-677.

(25) Muller, L.; Comte, P.; Czerwinski, J.; Kasper, M.; Mayer, A. C. R.; Gehr, P.; Burtscher, H.; Morin, J. P.; Konstandopoulos, A.; RothenRutishauser, B. New exposure system to evaluate the toxicity of (scooter) exhaust emissions in lung cells in vitro. Environ. Sci. Technol. 2010, 44 (7), 2632-2638.

(26) Steiner, S.; Czerwinski, J.; Comte, P.; Heeb, N.; Mayer, A.; Petri-Fink, A.; Rothen-Rutishauser, B. Reduction in (pro-)inflammatory responses of lung cells exposed in vitro to diesel exhaust treated with a non-catalyzed diesel particle filter. Atmos. Environ. 2013, 81 (2013), 117-124.

(27) Steiner, S.; Mueller, L.; Popovicheva, O. B.; Raemy, D. O.; Czerwinski, J.; Comte, P.; Mayer, A.; Gehr, P.; Rothen-Rutishauser, B.; Clift, M. J. D. Cerium dioxide nanoparticles can interfere with the associated cellular mechanistic response to diesel exhaust exposure. Toxicol. Lett. 2012, 214 (2), 218-225.

(28) Bunger, J.; Krahl, J.; Franke, H. U.; Munack, A.; Hallier, E. Mutagenic and cytotoxic effects of exhaust particulate matter of biodiesel compared to fossil diesel fuel. Mutat. Res., Genet. Toxicol. Environ. Mutagen. 1998, 415 (1-2), 13-23.

(29) Rothen-Rutishauser, B. M.; Kiama, S. G.; Gehr, P. A threedimensional cellular model of the human respiratory tract to study the interaction with particles. Am. J. Respir. Cell Mol. Biol. 2005, 32 (4), 281-289.

(30) Muhlfeld, C.; Rothen-Rutishauser, B.; Blank, F.; Vanhecke, D.; Ochs, M.; Gehr, P. Interactions of nanoparticles with pulmonary structures and cellular responses. Am. J. Physiol.: Lung Cell. Mol. Physiol. 2008, 294 (5), L817-L829.

(31) Morin, J. P.; Hasson, V.; Fall, M.; Papaioanou, E.; Preterre, D.; Gouriou, F.; Keravec, V.; Konstandopoulos, A.; Dionnet, F. Prevalidation of in vitro continuous flow exposure systems as alternatives to in vivo inhalation safety evaluation experimentations: Outcome from MAAPHRI-PCRD5 research program. Exp. Toxicol. Pathol. 2008, 60 (2-3), 195-205.

(32) Lichtveld, K. M.; Ebersviller, S. M.; Sexton, K. G.; Vizuete, W.; Jaspers, I.; Jeffries, H. E. In vitro exposures in diesel exhaust atmospheres: Resuspension of PM from filters versus direct deposition of PM from air. Environ. Sci. Technol. 2012, 46 (16), 9062-9070.

(33) Cooney, D. J.; Hickey, A. J. Cellular response to the deposition of diesel exhaust particle aerosols onto human lung cells grown at the air-liquid interface by inertial impaction. Toxicol In Vitro 2011, 25 (8), 1953-1965.

(34) Ghio, A.; Dailey, L. A.; Soukup, J. M.; Stonehuerner, J.; Richards, J. H.; Devlin, R. B. Growth of human bronchial epithelial cells at an air-liquid interface alters the response to particle exposure. Part. Fibre Toxicol. 2013, 10, 25.

(35) Lehmann, A. D.; Daum, N.; Bur, M.; Lehr, C. M.; Gehr, P.; Rothen-Rutishauser, B. M. An in vitro triple cell co-culture model with primary cells mimicking the human alveolar epithelial barrier. Eur. J. Pharmaceutics Biopharmaceutics 2011, 77 (3), 398-406.

(36) Clift, M. J.; Endes, C.; Vanhecke, D.; Wick, P.; Gehr, P.; Schins, R. P.; Petri-Fink, A.; Rothen-Rutishauser, B. A comparative study of different in vitro lung cell culture systems to assess the most beneficial tool for screening the potential adverse effects of carbon nanotubes. Toxicol. Sci. 2014, 137 (1), 55-64.

(37) Collins, A. R. The comet assay for DNA damage and repair: principles, applications, and limitations. Mol. Biotechnol. 2004, 26 (3), 249-61.

(38) Barnes, C. A.; Elsaesser, A.; Arkusz, J.; Smok, A.; Palus, J.; Lesniak, A.; Salvati, A.; Hanrahan, J. P.; Jong, W. H.; Dziubaltowska, E.; Stepnik, M.; Rydzynski, K.; McKerr, G.; Lynch, I.; Dawson, K. A.; Howard, C. V. Reproducible comet assay of amorphous silica nanoparticles detects no genotoxicity. Nano Lett. 2008, 8 (9), 3069-74.

(39) Kirsch-Volders, M.; Plas, G.; Elhajouji, A.; Lukamowicz, M.; Gonzalez, L.; Vande Loock, K.; Decordier, I. The in vitro MN assay in 2011: origin and fate, biological significance, protocols, high throughput methodologies and toxicological relevance. Arch. Toxicol. 2011, 85 (8), 873-99.

(40) Rombout, P. J.; Dormans, J. A.; Marra, M.; van Esch, G. J. Influence of exposure regimen on nitrogen dioxide-induced morphological changes in the rat lung. Environ. Res. 1986, 41 (2), 466-80. 